\title{
Comparisons of Financial Performance of Islamic Banks and Conventional Banks in Bangladesh
}

\author{
Mohammad Shamsu Uddin 1 \\ Mohammad Kamrul Ahsan ${ }^{*}$ \\ Md. Alaul Haque ${ }^{3}$ \\ ${ }^{1}$ PhD Candidate, Faculty of Management and Economics, Dalian University of Technology, P R China \\ $2^{2 *}$ Assistant Professor, Department of Business Administration, Metropolitan University, Sylhet, Bangladesh \\ ${ }^{3}$ Lecturer, Department of Business Administration, Metropolitan University, Sylhet, Bangladesh \\ (ahsan404243@gmil.com)* \\ Received 7 May, 2017
}

This journal is licensed under a Creative Commons Attribution-NonCommercial 4.0 International License (CC-BY-NC). Articles can be read and shared for noncommercial purposes under the following conditions:

- BY: Attribution must be given to the original source (Attribution)

- NC: Works may not be used for commercial purposes (Noncommercial)

This license lets others remix, tweak, and build upon your work non-commercially, and although their new works must also acknowledge you and be non-commercial, they don't have to license their derivative works on the same terms.

License Deed Link: http://creativecommons.org/licenses/by-nc/4.0/

Legal Code Link: http://creativecommons.org/licenses/by-nc/4.0/legalcode

$A B C$ Research Alert uses the CC BY-NC to protect the author's work from misuse.

\section{Abstract}

The study has been examined and compared the performance of Islamic and Conventional banks in Bangladesh during 2010 to 2014 by analyzing CAMEL tests standard factors such as capital adequacy, asset quality, management quality, earning ability and liquidity position. The financial data for this study have taken from the banks' financial statements existing on the banks' websites. A sample of 5 Islamic banks and 5 Conventional banks has been selected to measure and compare their performance. Each year the average ratios were considered. CAMEL tests which is a standard test to check the health of financial institutions was used to determine the performance of Islamic and Conventional banks. The researchers have used the t-tests to justify the data. The study has shown that statistically there is no significant difference between Islamic banks and Conventional banks based on their performance calculated by CAMEL except management quality. The management qualities and asset qualities of Conventional banks are better than that of Islamic banks. On the other hand, Capital adequacy and liquidity position of Islamic banks are better than that of Conventional banks.

\section{Keywords}

CAMEL, Islamic Banks, Conventional Banks, and Comparisons 


\section{Introduction}

A country's economic growth basically depends on the financial institutions especially banking sectors of that country. Banking sectors play an important role in the development of the economy. In Bangladesh, banking sector always performs well and there have two main pillars of the banking sector operating within the country i.e. Conventional and Islamic banks. Islamic banking has been a growing globally at a very fast pace. Islamic finance industry in Bangladesh has been in existence for more than 30 years. Bangladesh has a mixed banking system comprising nationalized, private and foreign commercial banks. At present there are 56 scheduled banks in Bangladesh consists of 6 state-owned commercial banks, 2 specialized banks, 39 private commercial banks \& 9 foreign- commercial banks. Private Commercial Banks (PCB) can be categorized into two groups: i) Conventional PCBs: 31 conventional $\mathrm{PCBs}$ are now operating in the industry. They perform the banking functions in conventional fashion i.e. interest-based operations. ii)Islami Shariah-based PCBs: There are 8 Islami Shariah-based PCBs in Bangladesh and they execute banking activities according to Islami Shariah-based principles i.e. Profit-Loss Sharing (PLS) mode (BB, 2016).

Islamic banking is very growing sector, while the conventional or Riba based banking is centuries old. But Islamic banking system has gained popularity so fast that there are more than 300 Islamic financial institutions all over the world with investment funds in excess of $\$ 400$ billion (El-Qorchi, 2005). UK, France, China, Singapore and many other countries have developed special regulatory to facilitate the working of Islamic banking. The market share of Islamic Banks has grown from around two percent in the 1970s to around fifteen percent in the 1990s (Aggarwal \& Yousef, 2000).

Islamic banking as a new paradigm started in Bangladesh in 1983 with the establishment of the first Islamic bank "Islami Bank Bangladesh Limited". The innovation of interest-free banking systems proved its worth in the country's money market and many new banks have been established to operate in compliance with Shariah and many traditional banks have opened their Islamic banking windows.

Islamic Banking means Islamic Shariah-based banking (without interest) i.e. goals, objectives, and activities are to be done according to the principles of Islamic Shariah. Conventional banking is based on interest and a pure financial intermediation model, whereby banks mainly borrow from savers and then lend to enterprises or individuals. They make their profit from the margin between the borrowing and lending rates of interest. They also provide other banking services, like letters of credit and guarantees. A proportion of their profit comes from the low-cost funds that they obtain through demand deposits.

\section{DIFFERENCES BETWEEN CONVENTIONAL AND ISLAMIC BANKS:}

The modes of operations between Islamic banks and conventional banks are different. The conventional banking operates on pre-fixed interest whilst Islamic banks based on profit sharing. The modes of operations are different. Islamic banking refers to a system of banking or banking activity that is consistent with Islamic law (Shari'ah) principles and guided by Islamic economics. In particular, Islamic law prohibits usury, the collection and payment of interest, also commonly called riba. Generally, Islamic law also prohibits trading in financial risk (which is seen as a form of gambling). The obvious different is the conventional banking operates on pre-fixed interest whilst Islamic banks based on profit and loss sharing. The conventional banks earn profits by attracting deposits from the depositors at a low-interest rate, then reselling those funds to the borrowers at higher interest rate, based on its competitive advantage at gathering information and underwriting risk. Therefore, 
conventional banks make profits from the spread between the interest rate received from borrowers and the interest rate paid to depositors (Mohamad, Hassan \& Bader, 2008).

\section{OBJECTIVE OF THE STUDY}

The main objective of this study is to measure and compare the financial performance of Islamic Banks and Conventional Banks in Bangladesh. The subsequent objective is to find out whether the Islamic or Conventional banks are operating efficiently.

\section{LIMITATIONS}

The main limitation of this study is that it can't be showed all the performance of conventional and Islamic banks of Bangladesh by considering 5 conventional and 5 Islamic banks. Other limitations are:

1. The researchers consider only 5 years data i.e. 2010 to 2014 due to unavailable of data.

2. The researchers use only six ratios to measure the performance.l

\section{METHODOLOGY OF THE STUDY:}

This study is basically based on the financial data which collected from their financial statements. The population for this study is the all Islamic and Conventional banks that operate inside Bangladesh. The sample size is comprised of 5 full-fledged Islamic and 5 Conventional banks. These 5 Islamic and 5 Conventional banks are selected randomly from 8 Islamic banks and 31 Conventional banks in Bangladesh. These selected banks are:

\begin{tabular}{|r|c|l|}
\hline Islamic Banks & & Conventional Banks \\
\hline Al-Arafah Islami Bank Limited & 1 & AB Bank Limited \\
\hline First Security Islami Bank Limited & 2 & Dutch-Bangla Bank Limited \\
\hline Islami Bank Bangladesh Limited & 3 & Mercantile Bank Limited \\
\hline Social Islami Bank Limited & 4 & National Bank Limited \\
\hline Shahjalal Islami Bank Limited & 5 & Prime Bank Limited \\
\hline
\end{tabular}

The financial data of all Islamic and Conventional banks were extracted from the respective website for the period 2010-2014. For better comparison, each year the average ratios for Islamic and Conventional banks were considered and then the mean of each ratio for each mode of banking was calculated.

To measure and compare the performance of Islamic and Conventional banks, CAMEL analysis is used, which is a standard test for performance analysis of financial institutions and the latest technique nowadays used. CAMEL test consists of Capital Adequacy, Asset quality, Management Quality, earning ability and Liquidity. To achieve the desired results the paper would be utilizing 6 ratios that define their respective parameters. These are mentioned in the following:

\begin{tabular}{|c|l|l|}
\hline Alphabet & Stands for & Measurement Ratio \\
\hline C & Judgment of Capital Adequacy & Total Equity to Total Asset \\
\hline A & Judgment of Asset Quality & Loan Loss Reserve Ratios \\
\hline M & Judgment of Efficiency and Quality of Management & Total Operating Expenses to Total Operating Income \\
\hline E & Judgment of the Volume and Level of Earnings & $\begin{array}{l}\text { Net Profit to Total Asset } \\
\text { Net Profit to Total Equity }\end{array}$ \\
\hline L & Judgment of Strength and Level of Liquidity & Net Loan to Total Assets \\
\hline
\end{tabular}


The researchers formulate hypothesis i.e.,

H0: There is no significant difference between Conventional and Islamic Banks in Bangladesh based on CAMEL.

H1: There is a significant difference between Conventional and Islamic Banks in Bangladesh based on CAMEL.

The study will apply the t-test to test the significance differences between the mean ratios of Islamic and conventional banks. This t-test has been performed using the Microsoft Excel 2007.

\section{LITERATURE REVIEW}

Islamic banking attributes to a banking system or enterprise that is persistent with Islamic laws and principles (Sharia). The practical applications of these principles must conform to Islamic laws and help develop Islamic economies. Islamic law prohibits the earning of interest on lending money, therefore, Islamic banks must not accept or pay interest during their daily business. But Conventional banking does not conform to Islamic principles. In conventional banking, interest is earned by lending money. It is based on a relationship between the debtor and creditor i.e. a person deposits the money into the bank and/or borrows the money from a bank. Interest is earned on deposits and lending by respective parties. Various studies have been conducted to compare the performance of Islamic banks with that of conventional banks. However, the volume of such study has been limited. This is due to the fact that the data of Islamic banks have been unavailable due to their recent growth. This section will focus and highlight the recent researches that have been conducted. This will give an idea as to the performance of Islamic and conventional banks in Bangladesh during the recent periods.

\section{CAMEL}

\section{a) Capital Adequacy}

The dimension of capital adequacy is an important factor to be measured by the banks. It can help the bank and its management in understanding the shock attractive capability during times of risk. In our study, capital adequacy will be measured by using the Equity to total assets ratio (EQTA) (Vong \& Chan, 2009). EQTA is reflected to be a degree of capital adequacy and will support our study in understanding the safety and financial reliability of the banks. This ratio will help us in defining the magnitude of assets that have been financed by owner's funds. The logic is that high EQTA ratio will aid the bank in providing a strong cushion for increasing its credit undertakings and lowering the unanticipated risks. Samad (2004) states, that high level of EQTA often supports the organization in charming asset losses. This implies that as the amount of the equity to back the assets of bank depresses, the bankruptcy risk of the bank intensifies. Also, Hassan and Bashir (2003) state that constant lowering of EQTA hints to an invitation of risk in the banks and therefore highlight the capital adequacy of the bank. Hence, we assume this ratio to be as higher as possible.

\section{b) Asset quality}

Asset quality will help the bank in increasingly understand the risk with respect to the exposure of a bank to the debtors. Asset quality in our study will be measured by loan loss reserves (LLR). LLR can be defined as an indicator to evaluate the value of loans by a bank. In other words, this performance parameter will benefit the bank in understanding a number of funds that have been reserved by the banks in event of bad loans. This suggests that LLR is 
an assurance to cover the bad and doubtful loans of the bank. Since this ratio delivers an image of the sum of the provision that has been kept aside for bad and doubtful loans, banks should focus and ensure that they uphold low provision for bad loans. Banks that maintain a high provision for bad loans should be concerned as this will signal towards future losses. Hence, in our study, we will assume this ratio to be as lower as possible.

\section{c) Management quality}

This measure of performance will shed light on the superiority of the management. The duty of the management is to safeguard that the bank's operation runs in a smooth and decent manner. Very often, the bank's superiority in terms of management is decided by the skill and ability of the management to control the cost and increase productivity, ultimately achieving higher profits. Hence, the cost to income ratio (COSR) will be utilized to measure the management quality. COSR can be extensively defined as the cost incurred by the organization to generate a dollar of income. COSR is one of the premium ratios to capture the management competence of the bank. By controlling the cost, it is meant to control the overhead cost that is sustained to run a bank. Hence, in our study we expect the COSR to be as lower as possible.

\section{d) Earnings}

Earnings being one of the performance parameters highlights on the bank's prevailing and forthcoming activities with respect to its earnings. It essentially adds the bank in concentrating on the loss gripping capacity, determining the level of its earnings and revenue as well as the funds available for rewarding its shareholders. Our study would be employing two performance measures to determine the profitability of the banks. These are returned on assets (ROA) and return on equity (ROE). ROA fundamentally sheds light and specifies the ways that management exploits its assets to generate earnings. ROA is also an indicator of operational efficiency (Petersen \& Schoeman, 2008). In simple words, ROA will deliver us with information on the amount of income generated from the each unit of an asset on an average. ROE, on the other, hand is a measurement that contributes in understanding the working of the management of the organization with respect to the earnings or income generated from the owner's equity. ROE can be defined to measure the returns on the equity holders in order to evaluate the growth on their investments. Petersen \& Schoeman (2008) state that the banks maintain sufficient capital to avoid failure, but banks should ensure that they do not hold extra capital. Hence, an association can be established where higher the equity capital, the lower the ROE.

\section{e) Liquidity}

This parameter of performance can aid the banks and establishments to evaluate the risk faced by the banks in case of an unprecedented and unforeseen circumstance that can be the main reason for an insolvency of the bank. To assess the liquidity of the banks, we would be using the net loan to total assets (NLTA). NLTA can be defined as a number of assets that have been engaged in loans. Hassan \& Bashir (2003) found that the NLTA should be as lower as possible. High NLTA will often result in inferior liquidity standards of the bank. The only reason being, that high NLTA indicates that the bank is engaged highly in lending and this may have adverse effects as the bank might face a huge risk of defaulters. Hence, in our study, we expect this ratio to be as lower as possible. 
Merchant (2012) studied and compared Gulf Cooperation Council (GCC) during the period of $2008-2011$ by deploying the CAMEL testing factors using 2 tailed t-test and found that Islamic banks possessed adequate capital structure but have recorded lower ROAE and poor management efficiency. Asset quality and liquidity for both the modes of the banking system have not recorded any significant difference.

In a study piloted by Jaffar \& Manarvi (2011), the authors study a sample of 5 Islamic banks and 5 conventional banks in the Pakistan for a period of 2005-2009. The authors found that Islamic banks performed well in capital adequacy and liquidity while conventional banks performed better in earning and management quality. Asset quality remained the same in Islamic banks and conventional banks.

Akkas (1996) compared the efficiency of Islamic banking with conventional banking in Bangladesh. He found that the Islamic banks are comparatively more efficient than conventional banks.

Safiullah (2010) conducted research in Bangladesh to find out superiority among conventional banks and Islamic bank he stated that in perspective of productivity and efficiency interest-based conventional banks are doing the better performance than interest-free Islamic banks. But the performance of interest-free Islamic banks in business development, profitability, liquidity, and solvency are superior to that of interest-based conventional banks. That is comparatively Islamic banks are superior in financial performance to that of interest-based conventional banks.

Zeitun (2012) directed a study on the GCC for a period of 2002 - 2009, to evaluate the factors that influence the Islamic bank and conventional banks. The study included a sample of 38 conventional banks and 13 Islamic banks. The factors that were studied were foreign ownership, bank specific variable and macroeconomic variables. Some interesting results were found. The cost to income ratio and performance of the banks held a negative correlation for Islamic and conventional banks. Equity was found out to be an important factor in maximizing the profitability of Islamic banks. The size of the banks supported the economies of scale utilizing the ROE for Islamic banks. GDP was found to be positively related, while inflation negatively related to the bank's performance.

The Islamic bank Bangladesh, as a case in the region, has successfully developed and employed Islamic modes of banking. The performance of IBBL over the last 16 years has been continuously increasing. Performance is measured by using some additional variables as Bank's deposits, investment, remittances, and foreign exchange business. IBBL overall performance has been very significant in respect of mobilization of deposits, deployment of funds, operating results, capital adequacy ratio, provision for bad \& doubtful investments, liquidity, equity, profit paid to depositors, income from ancillary business, payment of dividend, return on equity and foreign exchange business (Ahmad, Hussain \& Hannan, 1999). To measure the efficiency of Islamic banks in Bangladesh, Sarker (1999) looked at the performance and operational efficiency of Bangladeshi Islamic banks and suggested that Islamic banks can survive even within a conventional banking framework. Islamic banks offer products and services which are very similar to conventional banks. However, the approaches of Islamic banks are clearly different from the ones of conventional banks.

As per best of our knowledge, there is no recent research conducted to compare financial performances of Conventional banks and Islamic banks by using CAMELS. The objective of 
this study is to compare the financial performance of Islamic banks with the conventional banks for the time period of five years i.e. 2011-2014. The results of this research work will answer the question that whether Islamic banking sector's performance outflanks conventional banking sector or not?

\section{ANALYSIS AND FINDINGS}

The researchers use CAMEL analysis to measure and compare the performance of Islamic Banks and Conventional banks in Bangladesh. The CAMEL test consists of Capital Adequacy, Asset quality, Management Quality, earning ability and Liquidity.

\begin{tabular}{|c|c|c|c|c|c|}
\hline & 2010 & 2011 & 2012 & 2013 & 2014 \\
\hline IB & 0.0855 & 0.0837 & 0.2408 & 0.2428 & 0.2422 \\
\hline CB & 0.1018 & 0.0937 & 0.0862 & 0.0868 & 0.0835 \\
\hline
\end{tabular}

Table 1: Capital Adequacy

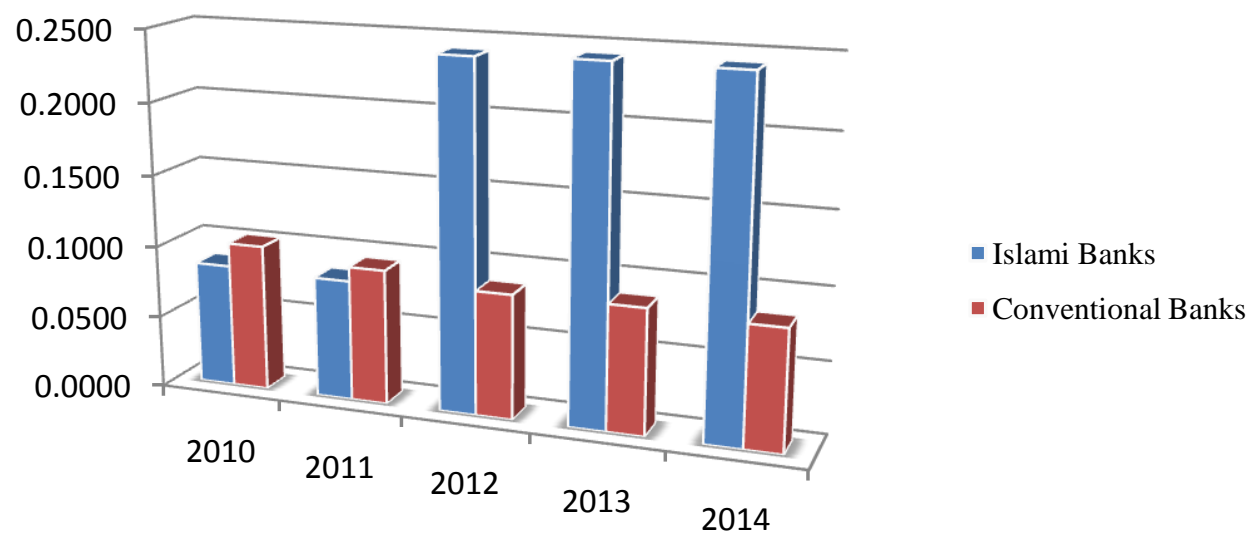

Figure 1: Capital Adequacy

From the table and figure 1, it is seen that Conventional banks' capital adequacy is almost same 2010 to 2014. On the other hand, Islamic banks' capital adequacy increases in 2012 to 2014 than the conventional banks.

\section{Hypothesis 1:}

H0: There is no significant difference between Conventional and Islamic Banks in Bangladesh based on Capital Adequacy.

H1: There is a significant difference between Conventional and Islamic Banks in Bangladesh based on Capital Adequacy

\section{Test of Hypothesis:}

\begin{tabular}{|l|l|}
\hline$t$ Stat & 2.75 \\
\hline $\mathrm{P}(\mathrm{T}<=\mathrm{t})$ two-tail & 0.07 \\
\hline $\mathrm{t}$ Critical two-tail & 3.18 \\
\hline
\end{tabular}

From the test, it is seen that the critical value (3.18) is greater than the t-value (2.75), and p-value (0.07) is greater than 0.05. So, it cannot be rejected the null hypothesis. The null hypothesis is accepted, that is there is no significant difference between Conventional and Islamic banks based on capital adequacy. Actually, there have some differences but that's not significant. 


\begin{tabular}{|l|r|r|r|r|r|}
\hline & 2010 & 2011 & 2012 & 2013 & 2014 \\
\hline IB & 0.0076 & 0.0069 & 0.0077 & 0.0059 & 0.0109 \\
\hline CB & 0.0047 & 0.0040 & 0.0130 & 0.0118 & 0.0120 \\
\hline \multicolumn{7}{|c}{ Table 2: Asset Quality }
\end{tabular}

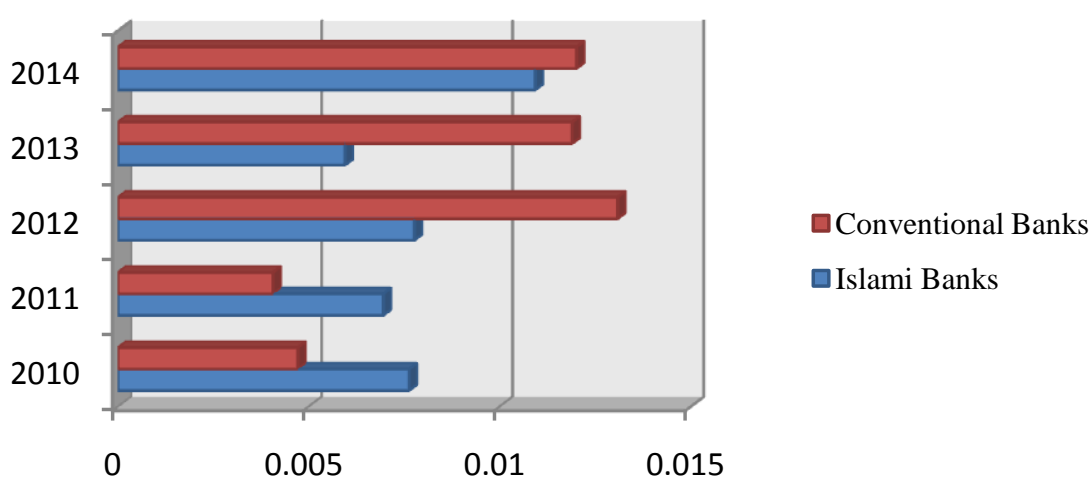

Figure 2: Asset Quality

From the figure 2, it is seen that conventional banks' asset quality is better than Islamic banks but not significant different between them. In 2012 and 2013, conventional banks' asset quality is more than Islamic banks.

\section{Hypothesis 2:}

$\mathrm{H}_{0}$ : There is no significant difference between Conventional and Islamic Banks in Bangladesh based on Asset Quality.

$\mathrm{H}_{1}$ : There is a significant difference between Conventional and Islamic Banks in Bangladesh based on Asset Quality.

\section{Test of Hypothesis:}

\begin{tabular}{|l|l|}
\hline $\mathrm{t}$ Stat & 1.14 \\
\hline $\mathrm{P}(\mathrm{T}<=\mathrm{t})$ two-tail & 0.33 \\
\hline $\mathrm{t}$ Critical two-tail & 3.18 \\
\hline
\end{tabular}

From the test, it is seen that t-value (1.14) is lower than the tabular value (3.18) and p-value (0.33) is greater than 0.05 . Thus, it cannot be rejected the null hypothesis. That is, there is no significant difference between Conventional and Islamic Banks based on Asset Quality.

\begin{tabular}{|l|r|r|r|r|r|}
\hline & 2010 & 2011 & 2012 & 2013 & 2014 \\
\hline IB & 0.3509 & 0.3470 & 0.3602 & 0.4525 & 0.4572 \\
\hline CB & 0.3460 & 0.3854 & 0.5066 & 0.5222 & 0.5769 \\
\hline
\end{tabular}

Table 3: Management Quality

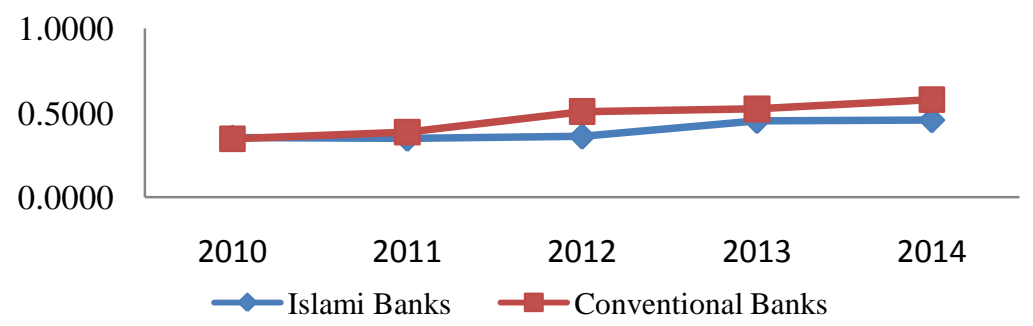

Figure 3: Management Quality 
From the figure 3, it is seen that in the year 2010 and 2011 the management quality is about to same for the conventional banks and Islamic banks. But after 2011, conventional banks' management quality is increased.

\section{Hypothesis 3:}

H0: There is no significant difference between Conventional and Islamic Banks in Bangladesh based on Management Quality.

H1: There is a significant difference between Conventional and Islamic Banks in Bangladesh based on Management Quality.

\section{Test of Hypothesis:}

\begin{tabular}{|l|l|}
\hline$t$ Stat & 3.85 \\
\hline $\mathrm{P}(\mathrm{T}<=\mathrm{t})$ two-tail & 0.03 \\
\hline $\mathrm{t}$ Critical two-tail & 3.18 \\
\hline
\end{tabular}

From the test, it is seen that calculated t-value (3.85) is greater than the tabular value (3.18) and p-value (0.03) is less than 0.05. Thus, the null hypothesis is rejected and the alternative hypothesis is accepted. That is, there has a significant difference between Conventional and Islamic Banks based on Management Quality.

\begin{tabular}{|l|r|r|r|r|r|}
\hline & 2010 & 2011 & 2012 & 2013 & 2014 \\
\hline IB & 0.0173 & 0.0126 & 0.0121 & 0.0095 & 0.0077 \\
\hline CB & 0.0241 & 0.0191 & 0.0100 & 0.0093 & 0.0084 \\
\hline
\end{tabular}

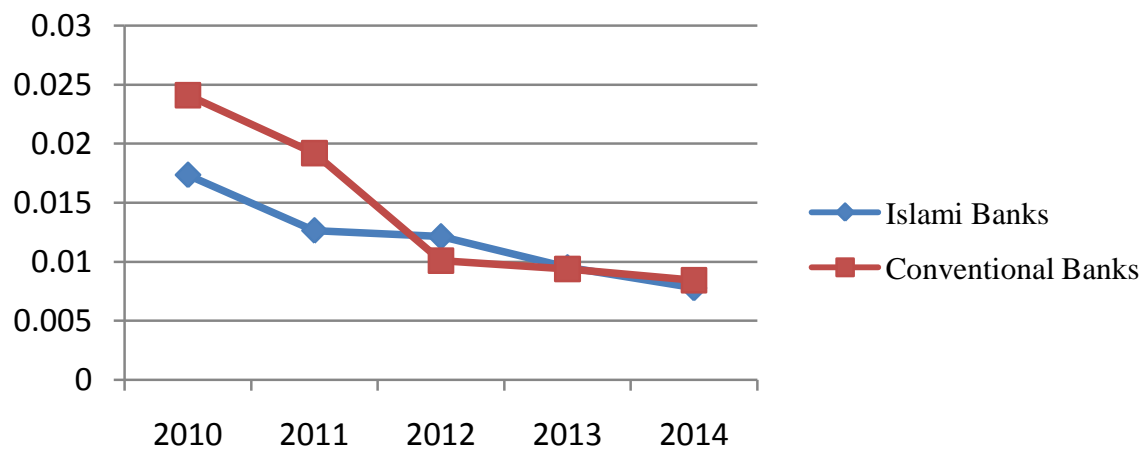

Figure 4: Earnings: Net Profit to Total Asset

From the figure 4, it is found that conventional and Islamic banks have different earnings in 2010 and 2011 but in 2012, 2013 and 2014 they are almost same.

\section{Hypothesis 4:}

H0: There is no significant difference between Conventional and Islamic Banks in Bangladesh based on Earnings: Net Profit to Total Asset.

H1: There is a significant difference between Conventional and Islamic Banks in Bangladesh based on Earnings: Net Profit to Total Asset.

Test of Hypothesis:

\begin{tabular}{|l|l|}
\hline $\mathrm{t}$ Stat & 0.67 \\
\hline $\mathrm{P}(\mathrm{T}<\mathrm{t})$ two-tail & 0.54 \\
\hline $\mathrm{t}$ Critical two-tail & 3.18 \\
\hline
\end{tabular}

From the test, it is found that calculated t-value (0.67) is less than the tabular value (3.18) and p-value (0.54) is more than 0.05 . So, it can't be rejected the null hypothesis. That is, there is no significant difference between Conventional and Islamic Banks based on Earnings: Net Profit to Total Asset. 


\begin{tabular}{|l|r|r|r|r|r|}
\hline & 2010 & 2011 & 2012 & 2013 & 2014 \\
\hline IB & 0.1980 & 0.1503 & 0.1207 & 0.1008 & 0.0742 \\
\hline CB & 0.2525 & 0.1987 & 0.1242 & 0.1106 & 0.1019 \\
\hline \multicolumn{7}{|c|}{ Table 5: Earnings: Net Profit to Total Equity }
\end{tabular}

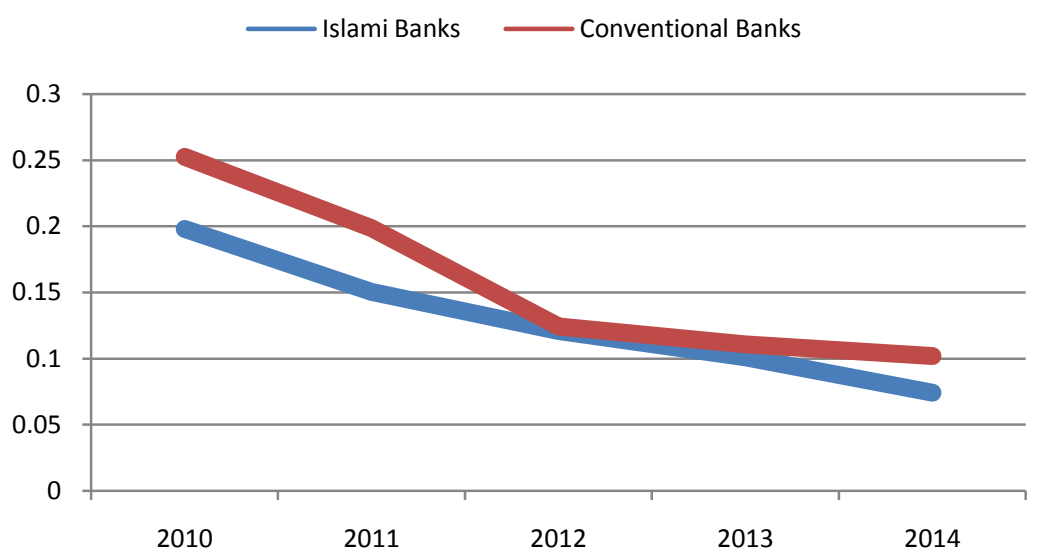

Figure 5: Earnings: Net Profit to Total Equity

From the figure 5, it is found that conventional and Islamic banks have different earnings in 2010 and 2011 but in 2012, 2013 and 2014 they are almost same and in the earnings purpose conventional banks are ahead (in 2010 and 2011).

\section{Hypothesis 5:}

H0: There is no significant difference between Conventional and Islamic Banks in Bangladesh based on Earnings: Net Profit to Total Equity.

H1: There is a significant difference between Conventional and Islamic Banks in Bangladesh based on Earnings: Net Profit to Total Equity.

\section{Test of Hypothesis:}

\begin{tabular}{|l|l|}
\hline $\mathrm{t}$ Stat & 2.21 \\
\hline $\mathrm{P}(\mathrm{T}<=\mathrm{t})$ two-tail & 0.11 \\
\hline $\mathrm{t}$ Critical two-tail & 3.18 \\
\hline
\end{tabular}

From the test results, it is found that the value of t-value (2.21) is less than the tabular value (3.18) and p-value (0.11) is greater than 0.05. So it can't be rejected the null hypothesis. Thus there is no significant difference between Conventional and Islamic Banks based on Earnings: Net Profit to Total Equity.

\begin{tabular}{|l|r|r|r|r|r|}
\hline & 2010 & 2011 & 2012 & 2013 & 2014 \\
\hline IB & 0.6741 & 0.6638 & 0.5414 & 0.6578 & 0.6688 \\
\hline CB & 0.6917 & 0.6357 & 0.5985 & 0.6209 & 0.6292 \\
\hline
\end{tabular}

Table 6: Liquidity

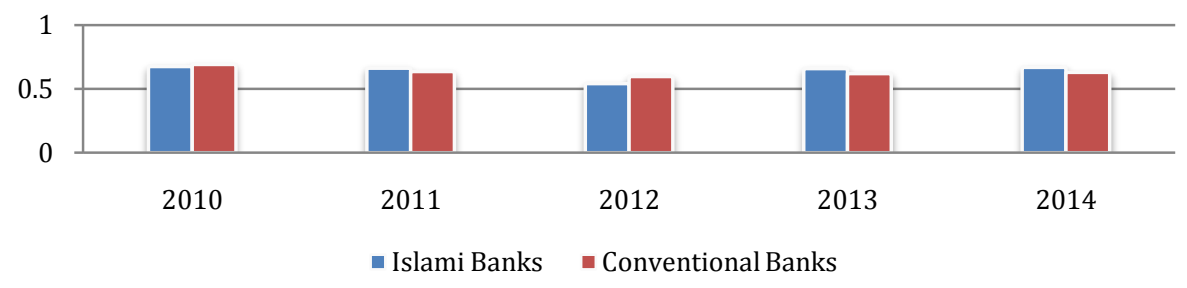

Figure 6: Liquidity 
From the figure 6 , it is clear that in the liquidity purpose conventional and Islamic banks are almost same.

\section{Hypothesis 6:}

H0: There is no significant difference between Conventional and Islamic Banks in Bangladesh based on Liquidity.

H1: There is a significant difference between Conventional and Islamic Banks in Bangladesh based on Liquidity.

\section{Test of Hypothesis:}

\begin{tabular}{|l|l|}
\hline$t$ Stat & 0.51 \\
\hline $\mathrm{P}(\mathrm{T}<\mathrm{t})$ two-tail & 0.64 \\
\hline $\mathrm{t}$ Critical two-tail & 3.18 \\
\hline
\end{tabular}

From the test, it is found that t-value (0.51) is less than the critical vale (3.18) and p-value (0.64) is greater than 0.05 . So it can't be rejected the null hypothesis. That is there is no significant difference between Conventional and Islamic Banks based on Liquidity.

\begin{tabular}{|c|c|c|}
\hline Alphabet & IB & CB \\
\hline C & 0.1789 & 0.0904 \\
\hline A & 0.0078 & 0.0091 \\
\hline M & 0.4305 & 0.4674 \\
\hline E & 0.0118 & 0.0142 \\
& 0.1288 & 0.1576 \\
\hline L & 0.6412 & 0.6352 \\
\hline \multicolumn{3}{|c|}{ Table 7: CAMEL }
\end{tabular}

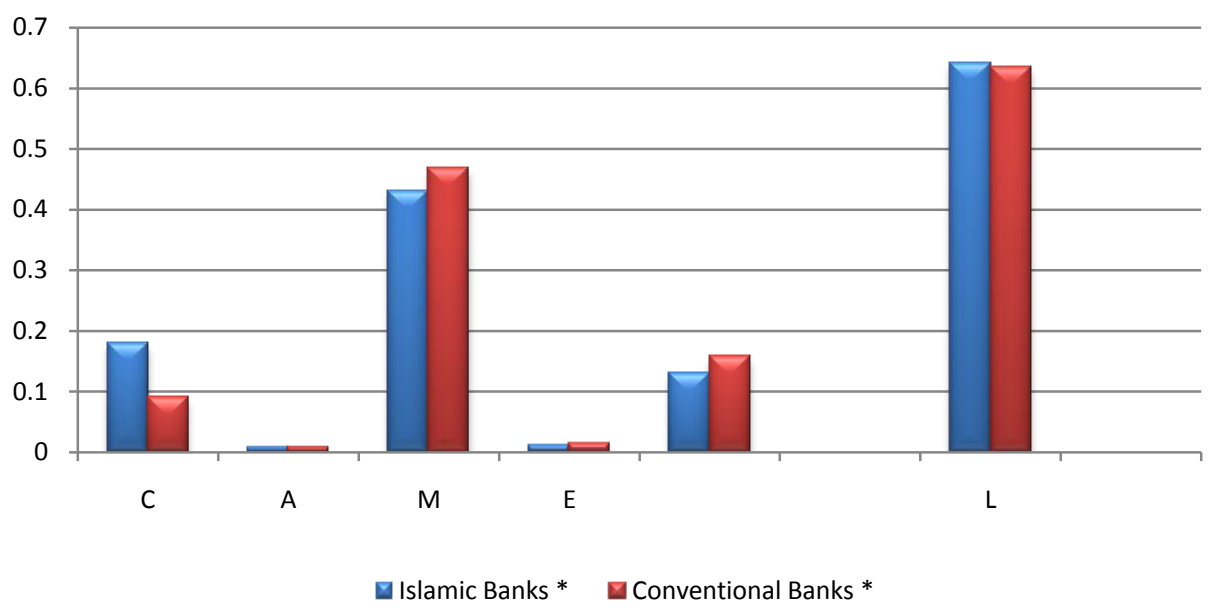

Figure 7: CAMEL

From the figure 7, it is seen that there have some difference between conventional banks and Islamic banks, but that is not significant ( $\mathrm{t}$ test result shows). They are almost same.

\section{Hypothesis 7:}

H0: There is no significant difference between Conventional and Islamic Banks in Bangladesh based on CAMEL

H1: There is a significant difference between Conventional and Islamic Banks in Bangladesh based on CAMEL

\section{Test of Hypothesis:}

\begin{tabular}{|l|l|}
\hline $\mathrm{t}$ Stat & 1.49 \\
\hline $\mathrm{P}(\mathrm{T}<=\mathrm{t})$ two-tail & 0.20 \\
\hline $\mathrm{t}$ Critical two-tail & 2.77 \\
\hline
\end{tabular}


Here, calculated t-value (1.49) is less than the tabular value (2.77) and p-value (0.20) is greater than 0.05 (not significant). So, it can't be rejected the null hypothesis. That is there is no significant difference between the conventional banks and Islamic banks based on CAMEL.

*Note: Source: Authors' Compilation, 2016; Table 7: Average value of 2010 to 2014

\section{CONCLUSION}

The researchers compare the financial performance of selected Islamic banks and Conventional banks operate within the country by using financial statements' data from 2010 to 2014. The findings show that there is no significant difference between two types of banks except management quality. Trend analysis also shows that the management qualities and asset qualities of Conventional banks are better than that of Islamic banks. On the other hand, Capital adequacy and liquidity position of Islamic banks are better than that of Conventional banks. Every study has a scope for further study. This study has been performed on the 5 Islamic and 5 conventional banks based in Bangladesh. To get a better understanding it would be interesting to analyze similar objectives by including all banks operate within this country. This will simultaneously increase the sample size which would provide a more detailed outlook on the performance of the two banking systems.

\section{References}

Bangladesh Bank. (2016). Financial System, Banks \& FIS, (online). Retrieved from https://www.bb.org.bd/fnansys/bankfi.php, on December 15, 2016

Aggarwal, R., \& Yousef, T. (2000). Islamic Banks and Investment Financing. Journal of Money, Credit and Banking, 32 (1), 93-120.

Ahmad, M. F., Hussain, M. S. \& Hannan, S.A. (1999). Experiences in Islamic Banking: A Case Study of Islamic Bank Bangladesh. Dhaka: Institute of Policy Studies

Akkas, A. (1996). Relative Efficiency of the Conventional and Islamic Banking System in Financing Investment. Ph.D. Dissertation, Dhaka University.

El-Qorchi, M. (2005). Islamic Finance Gears Up. Finance and Development, 42(4), 46-50.

Hassan, M. \& Bashir A. (2003). Determinants of Islamic Banking profitability, Paper presented at the Economic Research Forum (ERF) 10th Annual Conference, Marrakesh, Morocco, 16-18 December

Jaffar, M., \& Manarvi, I. (2011). Performance comparison of Islamic and Conventional banks in Pakistan, Global Journal of Management and Business Research. Vol 11(1), pp 1-7

Merchant, P. (2012). Empirical Study of Islamic Banks Versus Conventional Banks of GCC, Global Journal of Management and Business Research, Volume 12, Issue 20 Version 1.0.

Mohamad, S., Hassan,T. \& Bader, M. (2008). Efficiency of conventional versus Islamic Banks : international evidence using the Stochastic Frontier Approach (SFA), Journal of Islamic Economics,Banking and Finance, 4(2), pp. 107-130

Petersen, M \& Schoeman, I. (2008). Modeling of Banking Profit via Return-on-Assets and Return-on-Equity, Proceedings of the World Congress on Engineering, 2, pp. 1-6

Safiullah, M. (2010). Superiority of Conventional Banks \& Islamic Banks of Bangladesh: A Comparative Study”, International Journal of Economics and Finance, Vol. 2, No. 3.

Samad, A. (2004). Performance of Interest-Free Islamic Banks Vis-⿳亠丷⿵-Vis Interest-Based Conventional Banks of Bahrain, IIUM Journal of Economics and Management, 12(2), pp. 1-15

Sarker, M. A. A. (1999). Islamic banking in Bangladesh: performance, problems, and prospects, International Journal of Islamic Financial Services, Vol. 1 No. 3, pp. 15-36.

Vong, A. \& Chan, H. (2009). Determinants of Bank Profitability in Macau, Macau Monetary Research Bulletin, 12, pp. 93-113

Zeitun, R. (2012). Determinants of Islamic and Conventional Banks Performance in GCC Countries Using Panel

Data Analysis, Global Economy and Finance Journal, 5 (1), pp. 53-72 